\title{
Journal of Tourismology
}

Submitted: 23.09.2019

Revision Requested: 31.10.2019

Last Revision Received: 01.02.2020

\section{Potential Unexplored? Tourism and Economic Growth of Bangladesh}

\author{
Basharat Hossain ${ }^{1} \mathbb{0}$, Syed Naimul Wadood ${ }^{2}$ (])
}

\begin{abstract}
This paper examines the potential effects of tourism on the economic growth of Bangladesh. It is a review paper of the literature based on secondary data. This paper discusses various aspects regarding the effects of the tourism industry on the overall economic progress of the country, including real GDP growth, infrastructural development and employment generation. Since the tourism industry has a small share of revenue to the GDP of Bangladesh's economy (at this moment), its contribution to economic growth is limited till now. This paper finds that the current size of the Bangladesh tourism economy is BDT 500 million. Besides, Bangladesh earned USD 1157 million from tourism sector during 2009-2018 period. Each year, 0.55 million tourists (on average) visit Bangladesh in the same period. Moreover, it creates 2.23 million jobs each year. The travel and tourism sector contributes $4.4 \%$ of the GDP in each year. Bangladesh's government ensures a lot of facilities for tourists.This article points out a number of issues that need to be considered in the tourism industry to play a more significant role regarding economic growth, and the overall socio-economic development of Bangladesh.
\end{abstract}

\section{Keywords}

Impact, Tourism, Economic growth, Economic development, Banglades

\section{JEL Classification}

Z30, Z32

1 Correspondence to: Basharat Hossain (Asst. Prof.), International Islamic University Chittagong, Faculty of Economics, Department of Business Administration, Chattagram, Bangladesh. E-mail: basharatdu@gmail.com ORCID: 0000-0001-6140-5392

2 Syed Naimul Wadood (Assoc. Prof.), University of Dhaka, Department of Economics, Dhaka, Bangladesh.

E-mail: snwadood@econdu.ac.bd ORCID: 0000-0001-7424-7282

To cite this article: Hossain, B., \& Wadood, S. N. (2020). Potential unexplored? Tourism and economic growth of Bangladesh. Journal of Tourismology, 6(1), 63-77. https://doi.org/10.26650/jot.2020.6.1.0031 


\section{Introduction}

Bangladesh is currently the $41^{\text {st }}$ of the largest economy of the world and the second largest economy of South Asia, only next to India. Bangladesh is a south Asian and lower-middle-income country with around 163.7 million populations. The current size of Bangladesh's GDP is USD 286 billion, with 8.13 per cent growth rate in 2018 19 and it is estimated to be the 24th world largest economy by 2033 (Bangladesh Economic Review (BER) 2019, Centre for Economics and Business Research (CEBR), (2018). Apart from the service sector, the industry sector is the highest contributing sector in this economy (35.14 per cent) followed by agriculture (13.61 per cent), transport and communication sectors (10.98 per cent) respectively (BER, 2019). The industry sector covers four sub-sectors; these are: "mining and quarrying, manufacturing, electricity, gas and water supply and construction."

Table 1

The Bangladesh Economy: At A Glance

\begin{tabular}{ll}
\hline GDP & 286 Billion USD (2018-19 Prov.) \\
GDP Growth Rate & 8.13 per cent (2018-19 Prov.) \\
GDP Per Capita & USD 1,827 (2019) \\
Population (in Million), Estimated & 163.7 (2018) \\
Labor Force Participation Rate & 58.2 per cent (2016-17) \\
Literacy Rate (7 Years and Above) & 72.3 (Both Sexes), 74.3 (Male), 70.2 (Female), all 2017 \\
Life Expectancy at Birth (Yrs) & 72.0 (Both Sexes), 70.6 (Male),73.5 (Female), all 2017 \\
Incidence of Poverty & 21.8 per cent (Upper),11.3 per cent (Lower) (2018estimated) \\
Industry Contribution to GDP & 35.14 per cent (2018) \\
Transportation (Km.) & Road: 21,596(uptil Feb 2019) (includes 3,906 National)Rail: 3,956 \\
Inflation Rate (Average) & $(2017-18)$ \\
Workers' Remittances & 5.44 per cent (2017) \\
Savings (asper cent of GDP) & 11,869 Million USD(July-March 2019) \\
Investment (as per cent of GDP) & 31.56 (Total Investment) 8.17 (Public) 23.4(Private) (2018-19 Prov.) \\
Current Account Balance & (Negative) USD 4,270 Million (July-February 2019) \\
Export Earnings (f.o.b.) & 27,563 Million USD(July-March 2019), of which: Ready-made \\
Import Payments (f.o.b.) & Garments and Knitwear Combined: 23,126 Million USD \\
Earnings from Tourism & 37,839 Million USD (July-March 2019) \\
Budget Deficit (including foreign & 344 Million USD (2017) \\
grants, per cent of GDP) & 4.97 \\
\hline Sourc: BER (2019), Banglional) (2018-19 Prov.) \\
\end{tabular}

Source: BER (2019), Bangladesh Bureau of Statistics (BBS) (2019)

Correspondingly, the agriculture sector of Bangladesh consists of crops, animal farming, forests, and fishing. Around 40.6 per cent of the total labor force is involved in the agriculture sector, whereas another 20.4 per cent is involved in the industry sector. Transport, storage, and communication sector comprise of land, water and air transport, seaport transport, storage, and telecommunications. Moreover, the Bangladesh economy holds approximately 0.40 per cent of the world economy's GDP (Trading Economics, 2019). 
The ready-made garments and knitwear are the largest source (83.9 per cent) of the total export earnings (BER 2019). All other sectors (such as jute goods, frozen food, agricultural products, etc.) jointly contribute the remaining 16.1 per cent. Hence it is needed that other sectors grow fast, to reduce heavy export earnings dependence on the ready-made garments and knitwear industry. We argue that tourism is one of the best prospective sectors of Bangladesh to raise foreign exchange earnings, and this can contribute to additions to economic development as well. Because it has a large number of tourist spots, exquisite natural sights, pleasant environment, and tourist-friendly weather, the amiable behavior of the people, safety and security of the tourists, etc. Bangladesh earned an annual total of USD 344 million in 2017, USD 214.3 million in 2016, USD 150.3 million in 2015, way up from USD 79 million in 2006, from tourism revenue (Choice for Economic and Investment Research (CEIC), 2019). The number of tourist arrivals was at 830,068 in 2016 and 643,094 in 2015 (op. cit.). One point to be noted is that Bangladesh did not achieve significant success in utilizing the tourism and travel sector as compared to her Asian neighbors, such as Malaysia, Thailand, India, and China. For example, in 2013, the (percentage) total contribution to GDP of tourism with regards to Bangladesh, Malaysia, Thailand, India and China was 4.4, 16.1, 20.2, 6.2 and 9.2 respectively, the same lowest position with regards to total contribution to employment and capital investment in the tourism sector as well. As for information, in 2013-14, tourism directly contributed around 2.1 per cent to Bangladesh's GDP and supported 1.3 million jobs (Planning Commission (2015), Table 5.3, pp. 270).

The goal of this paper is to assess the contribution of tourism on the economic progress of Bangladesh. The organization of the paper is as follows. Section one is the background of the study, whereas section two describes the objective of the study, and section three is the overview of the literature. Section four describes the methodology, while section five exhibits statistical results, and section six provides recommendations and section seven concludes the article.

\section{An Overviewof the Concept of Tourism}

Tourism refers to the businesses that offer the services (e.g., transport, tourist spot for visiting, or entertaining) for the person seeking to enjoy a vacation (Tourism, 2019). The Collins dictionary delineates tourism as the commercial activities that arrange the facilities for the people on holiday (Tourism, 2019a). Moreover, tourism can be defined as the guidance and management of tourists (Tourism, 2019b). The United Nations World Tourism Organization (UNWTO) defines tourism in the following sentence: "Tourism includes the actions of people visiting to and staying in locations outer of their living place for equal or less than one successive year for relaxation, trade, and other intentions"(UNWTO, 2010) (see Camilleri (2018) for a review of the literature regarding the recent advancements in the tourism industry). 


\section{A Brief Overview of the Tourism Industry of Bangladesh}

Bangladesh has a large number of tourist spots with fanciful natural sights and beauties. The tourist sites include sea beaches, waterfalls, seaports, river ports, mountains, tea gardens, mangrove forests, roadside green views, safari parks, ecoparks, etc. Other tourist spots include historical monuments, religious monuments, museums, military museums, zoos, entertainment parks, children parks; etc. Table 2 highlights some renowned tourist spots of Bangladesh.

Table 2

Tourists Spots of Bangladesh: At a Glance

\begin{tabular}{|c|c|}
\hline Nature of Tourist Spots & Name of Tourist Spots \\
\hline & $\begin{array}{l}\text { Cox's Bazar Beach (longest natural, unbroken sea beach in the world, } \\
\text { stretching } 120 \text { kilometers, a top tourist destination), Inani Beach, Himchori } \\
\text { Waterfall and Hill Track, Laboni Beach, } 100 \text { Feet Buddha Statue. Ramu, }\end{array}$ \\
\hline Sea Beaches and its & Ukhia, Bandarban, Rangamati, Sonadia Island, Patenga, Parkir Char, Teknaf, \\
\hline \multirow[t]{2}{*}{ Adjacent Locations } & Saint Martin's Island and Sea Beach, Chandranath Hills (Sitakunda), Sajek \\
\hline & $\begin{array}{l}\text { Valley (Rangamati), Nilachal (Bandarban), Kuakata Sea Beach (number two } \\
\text { tourist destination), Katka (Sundarbans) }\end{array}$ \\
\hline \multirow[t]{3}{*}{ Natural Parks } & $\begin{array}{l}\text { Banghabandhu Sheikh Mujib Safari Park (Gazipur), Dulhajra Safari Park } \\
\text { (Chattagram), Sitakunda Eco Park (Chattagram), Madhabkunda Eco Park } \\
\text { (Moulavibazar), Madhutila Eco Park (Sherpur) }\end{array}$ \\
\hline & $\begin{array}{l}\text { Himchori (Cox’s Bazar), Madhabkunda (Maulvibazar), Pangthumai } \\
\text { (Sylhet), Hum Hum (Sreemangal), Richhang (Khagrachhari), Shoilo }\end{array}$ \\
\hline & Propat (Bandarban), Rijuk Jhorna (Bandarban), Amia khum (Bandarban), \\
\hline \multirow[t]{2}{*}{ Waterfalls } & $\begin{array}{l}\text { Khaiyyachara Falls (Chattagram),Tinap Saitar (Bandarban), Nafa-khum } \\
\text { (Bandarban), Shuvolong (Rangamati), Haja Chora (Khagrachari), Jadipai and } \\
\text { Baklai Fountains (Bandarban), Jaflong (Sylhet), Songrampunji (Sylhet) }\end{array}$ \\
\hline & Chattogram Division: Bandarban, Rangamati, Khagrachari, Sitakunda \\
\hline \multirow[t]{2}{*}{ Hills and Mountains } & $\begin{array}{l}\text { (Chattogram), Cox's Bazar District } \\
\text { Sylhet Division: Zaflong }\end{array}$ \\
\hline & Mymenshing Division: Garo Hills \\
\hline Islands & $\begin{array}{l}\text { Saint Martin's Island, Nijhum Dwip, Dublar Char, Burir Char, Bhola Island } \\
\text { (the country's largest island), Sandwip, Urir Char, Swarna Dweep, Hatiya, } \\
\text { Manpura Island, Maheshkhali Island, Char Kukri Mukri, Char Lakshmi, } \\
\text { Kutubdia, Sonadia }\end{array}$ \\
\hline \multirow[t]{2}{*}{ Forests } & $\begin{array}{l}\text { Sundarban Mangrove Forests (Khulna), Lawachora National Forests } \\
\text { (Sreemangal), Ratargul Swamp Forest (Sylhet) }\end{array}$ \\
\hline & Natore Rajbari (Natore), Ahsan Manzil (Dhaka City), Lalbag Fort (Dhaka \\
\hline \multirow{3}{*}{$\begin{array}{l}\text { Historical Palaces and } \\
\text { Monuments }\end{array}$} & City), Huseni Dalan (Dhaka), Muktagacha Palace (Mymensingh), Silaidaha \\
\hline & $\begin{array}{l}\text { Kuthibari (Kushtia), Jatiyo Smriti Soudho (Savar, Dhaka), Curzon Hall } \\
\text { (Dhaka City), the Mosque City of Bagerhat (Bagerhat) }\end{array}$ \\
\hline & $\begin{array}{l}\text { Mosque: Baitul Mukarrom Mosque (national mosque), Binot Bibir Mosque, } \\
\text { Shaat Gambuj Mosque, Tara Mosque, Khan Md.Mridha Mosque, Bibi Marium } \\
\text { Mosque, Al-Falah Mosque, Andarkillah Shahi Mosque, Kusumba Mosque } \\
\text { (Rajshahi), Choto Sona Mosque (Chapai Nawabganj), Shat Gombuj Mosque } \\
\text { (Bagerhat), Bagha Shahi Mosque (Rajshahi), Guthia Mosque (Barisal) }\end{array}$ \\
\hline \multirow{5}{*}{$\begin{array}{l}\text { Religious Monuments } \\
\text { and Places }\end{array}$} & Temple: Kantanagar Temple (Dinajpur) (finest terracotta temple), Adinath \\
\hline & $\begin{array}{l}\text { Temple (Maheshkhali), Chandranath Temple (Sitakunda), Dhakeswari Temple } \\
\text { (Dhaka), Puthia Temple Complex (Rajshahi) }\end{array}$ \\
\hline & Pagoda: Buddha Dhatu Jadi (Bandarban), Ramu Temple Complex (Cox’s \\
\hline & Bazar), Ukhia Pagoda Complex (Cox’s Bazar) \\
\hline & $\begin{array}{l}\text { Church: Armenian Church (Dhaka), St. Peter's Cathedral (Barisal), the Holy } \\
\text { Rosary Cathedral (Chattagram) }\end{array}$ \\
\hline
\end{tabular}


Shrines

National Institutions

Zoos

Museums

Archaeological Sites

Rivers

Lakes and Wetlands
Shrine of Hazrat Shah Jalal(Sylhet), Shrine of Hazrat Bayazid Bostami (Chattogram), Shrine of Hazrat Makhdum Shah (Rajshahi), Shrine of Lalon Shah (Kushtia)

Jatiyo Sangshod Bhaban (Dhaka City), Central Shaheed Minar (Dhaka City), Mouseleum of Father of the Nation Bangabandhu Sheikh Mujibor Rahman (Tungipara, Gopalganj), World War II Cemetery (Chattogram)

Bangladesh National Zoo (Dhaka),Chattagram Zoo and Veterinary Clinic, Comilla Zoo and Botanical Garden, Museum of Zoology (Dhaka), Rangpur Zoo, Rajshahi Central Zoo, Naria Zoo (Shariatpur), ShiteshBabu's Monster (Shreemangal), Shaheed A.H.M. Kamruzzaman Central Park \& Zoo(Rajshahi), Mini Zoo (Mymenshing), Khulna Zoo

National Museum (Dhaka City), Varendra Research Museum (Rajshahi), Ethnographical Museum (Chattagram)

Mahasthangarh (oldest archeological site), Somapura Mahavihara (Naogaon), Mainamati (Comilla), Sonargaon (Dhaka), Wari-Bateshwar (Narshingdi)

Padma, Meghna, Jamuna

Kaptai Lake (Rangamati), Tanguar Hoar (Sunamganj), Hakaluki Haor (Moulvibazar), Foy's Lake (Chattagram), Madhabpur Lake (Sylhet), Bichnakandi (Sylhet)

Source: Authors Own Compilation from Internet Sources

The tourism sector of Bangladesh is mainly led by the government tourism-related departments, and a large and vibrant private sector is also active and gradually emerging in recent years (encouraged to operate and at the same time, the policy is formulated, and regulation is made by the government tourism department). The tourism sector of Bangladesh is administered and supervised by the Bangladesh Parjatan Corporation (BPC) that was formed in 1972 by the Government of Bangladesh (See Table 3). Moreover, the stated primary objective of the BPC is to make Bangladesh an attractive tourist destination country, and the slogan has been "Beautiful Bangladesh." The BPC guides the public and private tourism organizations, ensures visa and immigration facilities for foreign tourists and seeks to ease the procedure, ensure security as well as the safety of the tourists.

Table 3

List of Tourism Administrations and Associations in Bangladesh

\begin{tabular}{cccc}
\hline Si No & Name & Web site & $\begin{array}{c}\text { Web site } \\
\text { Contents }\end{array}$ \\
\hline 1 & $\begin{array}{c}\text { Bangladesh Parjatan } \\
\text { corporation (BPC) } \\
\text { (Govt. Tourism Organization) }\end{array}$ & http://www.parjatan.gov.bd & $\begin{array}{c}\text { List of tourist spots and places, } \\
\text { hotel-motel booking, photo } \\
\text { gallery,list of hotel-motel, }\end{array}$ \\
2 & Bangladesh Tourism Board & http://www.tourismboard.gov.bd & $\begin{array}{c}\text { List of tourist spots and places, } \\
\text { video gallery }\end{array}$ \\
3 & $\begin{array}{c}\text { Tour Operators Association } \\
\text { of Bangladesh (TOAB) }\end{array}$ & http://www.toab.org & $\begin{array}{c}\text { List of 586 tour operators in } \\
\text { Bangladesh, list of tourist spots } \\
\text { and places, newsletter,blog, etc. }\end{array}$ \\
\hline
\end{tabular}

Source: Authors' Own Compilation 
In addition to this, BPC's other functions are: human resource formation for the tourism sector, encourage the public and private sector to join in the infrastructure as well as tourism-related projects, promote ecotourism (based on incorporating environmental and anthropological needs within tourism), and finally, improve the means of the tourism sector comprising tourist spot development, making new tourists spots, arranging safe hotels, motels, cottages, restaurants, picnic spots, rent-a-car, etc. (BPC 2019). Besides regulating private sector hotels and motels, the BPC on its own provides residential facilities through 25 hotels in 19 districts of Bangladesh.

The profession of tour guide as an early-career life employment has been popular in Bangladesh. Currently, more than 10,000 tour guides and more than 200 travel and tourism organizations are providing tourism services in Bangladesh (Airways office, 2019). Besides, tourism and hospitality management as an academic discipline has been introduced in graduate and postgraduate levels at the universities. At present, around seventy universities and institutions are offering Tourism and Hospitality Management courses and degrees in Bangladesh.

The tourism industry of Bangladesh suffers from inadequate budget and government supports, and insufficient roads in remote areas, and a small amount of publications, insufficient facilities for tourists, etc. During some periods of time in the past, political instability and violence created additional hindrance for tourism (see Sultana, 2016), whereas, currently the situation is much calmer and peaceful. Nevertheless, the prospects of tourism are comparatively much higher than the problems it faces. A large number of magnificent tourist spots, secure visa facilities, on arrival visa facilities for 60 countries, the lowest visa fee (as low as USD 51), no airport fees, a large number of tourist guides and agencies, easy to book transport tickets, both $\mathrm{AC}$ and non- $\mathrm{AC}$ private as well as public transports, currency conversion through banking and non-banking agents, fast internet speeds, tourist police for the safety and security of tourists, and so much more (Golden Bengal Tours, 2019).

\section{Objective of the Study}

The main goal of this paper is to inspect the impact of tourism on the economic growth of Bangladesh. More precisely, this article aims to present a general idea of the tourism industry of Bangladesh. Besides, it scrutinizes the contribution of the tourism sector on the economic growth, employment generation, and development of the tourist areas in Bangladesh.

\section{Overview of the Literature}

A large number of research works have been done on the economic growth and tourism of different countries, but very few descriptive works are found on the 
tourism of the Bangladesh economy. Table 4 highlights the previous research works and findings on Bangladesh tourism and the rest of the world, respectively.

Table 4

Impact of Tourism on the Bangladesh Economic Growth

\begin{tabular}{|c|c|c|c|c|}
\hline $\begin{array}{l}\text { Serial } \\
\text { No }\end{array}$ & Source & Topics of the Study & $\begin{array}{l}\text { Area of the } \\
\text { Study }\end{array}$ & Findings \\
\hline 1. & Kobra et al (2018) & Descriptive Study & Bangladesh & - \\
\hline 2. & Bhuiyan and Darda (2018) & Descriptive Study & Bangladesh & - \\
\hline 3. & Sayeda (2017) & Descriptive Study & Bangladesh & - \\
\hline 4. & Amin et al. (2017) & Newspaper Article (Descriptive) & Bangladesh & - \\
\hline 5. & Sultana (2016) & Descriptive Study & Bangladesh & - \\
\hline 6. & Rahman (2016) & Descriptive Study & Bangladesh & - \\
\hline 7. & Roy and Roy (2015) & Descriptive Study & Bangladesh & - \\
\hline 8. & Salam (2014) & Descriptive Study & Bangladesh & - \\
\hline 9. & Ali (2013) & Exploratory Factor Analysis & $\begin{array}{l}\text { Cox’s Bazar, } \\
\text { Bangladesh }\end{array}$ & $\begin{array}{l}\text { Positive } \\
\text { Impact }\end{array}$ \\
\hline 10. & Ali et al. (2012) & Descriptive Study, Ethics and Tourism & Bangladesh & - \\
\hline 11. & Das and Chakraborty (2012) & $\begin{array}{l}\text { t-test on GDP Growth,including and } \\
\text { excluding Tourism }\end{array}$ & Bangladesh & $\begin{array}{l}\text { Positive } \\
\text { Impact }\end{array}$ \\
\hline 12. & MOEF (2010) & $\begin{array}{c}\text { Project Paper, Descriptive Study, } \\
\text { Climate Change and Tourism }\end{array}$ & Bangladesh & - \\
\hline
\end{tabular}

Source: Compiled by the Authors

Kobra et al. (2018) discuss the good and bad features of promotion regarding investment in the tourism industry of Bangladesh. Some 120 stakeholders (both governmental and non-governmental) were interviewed for their views and opinions about this sector. Investment is insufficient, whereas lack of integration among the different authorities has been identified as one core problem of this sector.

Bhuiyan and Darda (2018) highlight the future possibilities of Halal tourism in Bangladesh. Bangladesh is the fourth largest Muslim populated country in the world and has a large number of Muslim shrines and congregations. Therefore, it has scopes for enhancements of Halal tourism (or Islamic Shariah-based).

Sayeda (2017) examines the prospects of economic, social, cultural, environmental effects of mass tourism in the context of Bangladesh, particularly in the context of Cox's Bazar and its surrounding areas. Mass tourism is geared towards convenient and economic tourism activities designed for a large number of tourists irrespective of their socio-economic status, and this can be one strategy for a large volume of tourism revenue generation. The concept of sustainable tourism that aims at preserving socio-cultural and natural resources of the tourist destination can be applied to the promotion of tourism in Cox's Bazar and its adjacent locations in a sustainable way, as per the paper.

Amin et al. (2017) discuss the problems and forecasts the prospective features of ruraltourism in the context of Bangladesh. Bangladesh, with a total count of 86,038 
villages, is in a perfect position to offer its green fields, wildlife, wetlands, river beds, rural festivals, arts, and crafts to visitors from home and abroad, whereas to keep in mind the plausible adverse effects as well. Sultana (2016) discusses how tourism affects different components of the Bangladesh economy by analyzing secondary data.

Among the other papers, Rhaman (2016) analyzes the impact of tourism on the livelihood of the residents of the Rangamati district in Bangladesh. Salam (2014) focuses on the significance of the socio-economic advantages of tourism in the context of Bangladesh. He clearly shows how the tourism sector earns revenues. Roy and Roy (2015) present an overview of the Bangladesh tourism industry. Ahmad, Shahab Uddin (2013) describes the present scenario, probable effects on the Bangladesh economy, training and product development issues and suggests many steps to expand the tourism sector in Bangladesh. Ali (2013) analyzes the socioeconomic influences of Tourism on Cox's Bazar-the largest sea beach in Bangladesh, and finds a positive impact. Das and Chakraborty (2012) examine the economic impact of tourism by t-test on GDP growth, including and excluding tourism and found a significant effect of tourism on the GDP of Bangladesh. Ali et al. (2012) discuss ethical issues related to tourism development in Bangladesh. The project paper of the Ministry of Environment \& Forests, Bangladesh highlights the effects of climate change on the tourism industry in Bangladesh (Ministry of Environment and Forests (MOEF), 2010). Ali and Parvin (2010) discuss how to treat tourism to increase its contribution to the GDP of Bangladesh.

Moreover, several studies tested the influence of tourism on the economic growth and advancement of other countries. Akan et al. (2007), Cetin (2014), Gökovali \& Bahar (2006) and Gokovali (2010) find that tourism, economic growth and GNP are strongly related to the Turkish economy. Kadir \& Karim (2012) and Puah et al. (2018) state the positive contribution of tourism on the Malaysian economic growth. De Esteban et al. (2015) and Ohlan (2017) concludes that tourism revenue, economic growth and financial development are strongly correlated to each other in the Indian economy. Stauvermann et al. (2016) illustrates the positive relationships among the tourism revenue, exchange rate, capital and economic growth of Sri Lanka. Yahya (2005) discusses the cost of damages incurred by tourism in the Maldives.

The previous studies cover a description of the tourism industry of Bangladesh, details of many tourist spots, prospects of rural tourism, problems and prospects of tourism, one research examines the t-test on the GDP with and without tourism revenue. Moreover, almost all of the earlier analyses (in Bangladesh perspective) were descriptive studies, and these combined the travel and tourism data. On the contrary, this paper separately, incorporates tourism revenue and travel $\&$ tourism revenue. Besides, it presents a complete idea about well-known and potential tourist spots and areas, 
tourism administration and tourism organization, facilities (Visa, accommodation, safety in travelling and currency exchange) for the tourists, and tourism education in Bangladesh. Finally, this paper analyzes data regarding Real GDP, tourism budget, tourism revenue, employment in the tourism sector through graphical analysis.

\section{Methodology}

This is an original research paper based on both qualitative and quantitative analyses. It incorporates the secondary data over the 2009-2017 period. Since the data on the tourism revenue of Bangladesh is not available before 2009, we considered the 2009-2017 period. The data are collected from the World Tourism Outlook 20092017, and the Bangladesh Economic Review (various editions). Data on real GDP, investment, tourism income are used in 2009 constant value of the USD. The data are analyzed by using mean, median, standard deviation and graphical analysis.

\section{Assessing the Impact of Tourism on the Economic Growth of Bangladesh}

The current size of the tourism industry of Bangladesh is BDT 5,000 crore in 2017, that was BDT 500 crore in 2007 (Rahman and Chakma, 2018). Bangladesh earned USD 1,153 million from the tourism sector during the 2009-2017 period (UNWTO, 2009-2018) while the revenue from the travel \& tourism sector was BDT 850.7 billion in 2017. On an average, a yearly number of 552,500 tourists visited Bangladesh during the 2009-2017 period. Table 5 explores the revenue of tourism, and travel \& tourism industry and its contribution in GDP and employment creation.

Table 5

Effect of Tourism on the Economic Growth of Bangladesh

\begin{tabular}{cccccc}
\hline Year & $\begin{array}{c}\text { Tourism } \\
\text { Revenue (In } \\
\text { million USD) }\end{array}$ & $\begin{array}{c}\text { No of } \\
\text { Tourist } \\
\text { visited }\end{array}$ & $\begin{array}{c}\text { Contribution of Travel } \\
\text { \& Tourism to GDP (In } \\
\text { Billion BDT) }\end{array}$ & $\begin{array}{c}\text { Job in } \\
\text { Travel \& } \\
\text { Tourism }\end{array}$ & $\begin{array}{c}\text { Contribution of Travel } \\
\text { \&Tourism to GDP } \\
\text { (Per Cent) }\end{array}$ \\
\hline 2009 & 70 & 267000 & - & - & 4.6 \\
2010 & 81 & 303000 & - & - & 4.7 \\
2011 & 87 & 440000 & 381.6 & 2880500 & 4.2 \\
2012 & 110 & 600000 & - & - & 4.3 \\
2013 & 128 & 618000 & 830 & 1328500 & 4.4 \\
2014 & 153 & 630000 & 627.9 & 1984000 & 4.5 \\
2015 & 148 & 648000 & 809.6 & 2346000 & 4.4 \\
2016 & 213 & 654000 & 840.2 & 2401000 & 4.3 \\
2017 & 337 & 700000 & 850.7 & 2432000 & 4.3 \\
2018 & - & - & - & - & 4.4 \\
$2025^{*}$ & - & - & $1,252.8$ & 2492000 & 6.1 \\
$2026 *$ & - & - & $1,783.0$ & 2894000 & 6.4 \\
$2027 *$ & - & - & $1,753.1$ & 2965000 & 4.7 \\
$2028^{*}$ & - & - & & - & 4.6 \\
\hline
\end{tabular}

Source: UNWTO (2009-2018), The World Travel \& Tourism Council (WTTC) (2009-2018), knoema.com (2019);

*Projected value. 
According to the reports of the WTTC, the travel \& tourism sector of Bangladesh generated approximately a yearly 2.23 million jobs during the 2011-2017 period. Tourism generates both formal and informal jobs. The most common form of formal job sectors are hotel and motel, cafe \& restaurant, shopping malls at the tourist site, transport, tourist guide, tourism agency, local handicrafts, etc. Besides, a large number of local people find their livelihoods in the informal sector, such as, rickshaw driving, hawkers, selling homemade food and non-food items, garbage collecting, unprofessional children singer,cameraman, and so much more. However, Table 6 and Figure 1 summarize the tourism contribution to real GDP of Bangladesh.

Table 6

Summary of the Tourism Contribution to Bangladesh Economy

\begin{tabular}{lccccc}
\hline Variable & Observation & Mean & Std. Dev. & Min & Max \\
\hline Real GDP (Bill \$) & 8 & 113.173 & 17.486 & 90.074 & 140.638 \\
Tourism Revenue (Bill \$) & 8 & 0.135 & 0.05 & 0.07 & 0.204 \\
Tourist Visited (Million) & 8 & 0.52 & 0.160 & 0.267 & 0.654 \\
Job in travel \& Tourism & 8 & 2.108 & 0.549 & 1.22 & 2.881 \\
(JTT) (Million) & & & & & \\
\hline
\end{tabular}

Furthermore, tourism sectors stimulate infrastructural development, development of residents of the tourists' spots, hotels, motels, production of food, and non-food items. In the last decade, Bangladesh experienced tremendous development in the tourism industry. A large number of new tourist spots were constructed around the country. At least ten natural fountains were discovered in the mountains. Besides, ten sea beaches were developed and renovated for the tourists. Moreover, the Bangladesh Roads and Highways Department constructed about ten thousand kilometres of roads to facilitate the tourists. Also, new rail lines and naval routes were developed, and private airlines facilities were introduced. More than 1700 hotels, motels, resorts were constructed around the country.
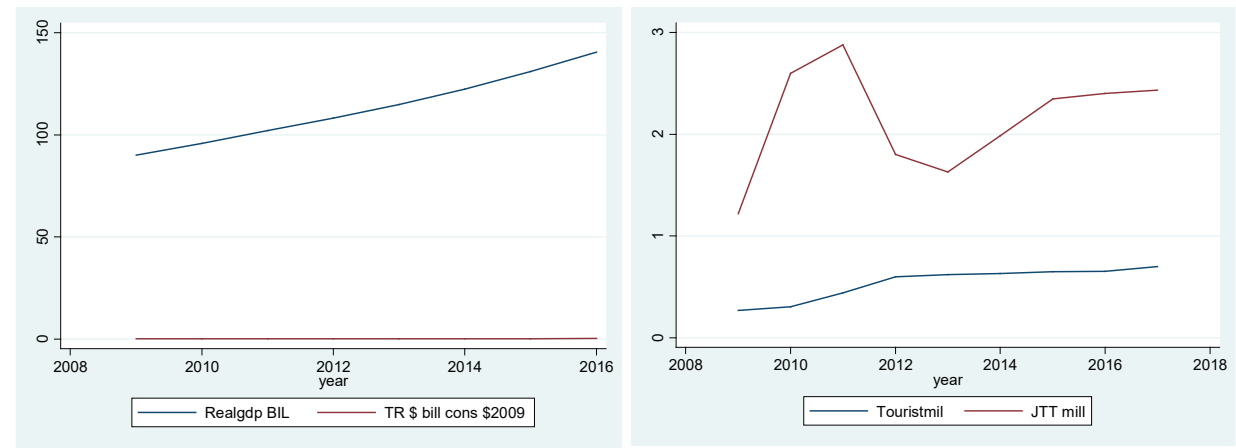

Figure 1. Real GDP and Tourism Contribution (Tourism Revenue, Tourist visited and Job in Travel \& Tourism (JTT) sector of Bangladesh for 2009-2017 
In the last decade, the Government of Bangladesh has increased the budget (4.87 times increases from 2009 to 2018) in the tourism industry which has opened a new horizon of economic growth and development by the additional revenues from the tourism sector. Figure 2 discloses the tourism budget and revenue for the last decade (2009-2018).

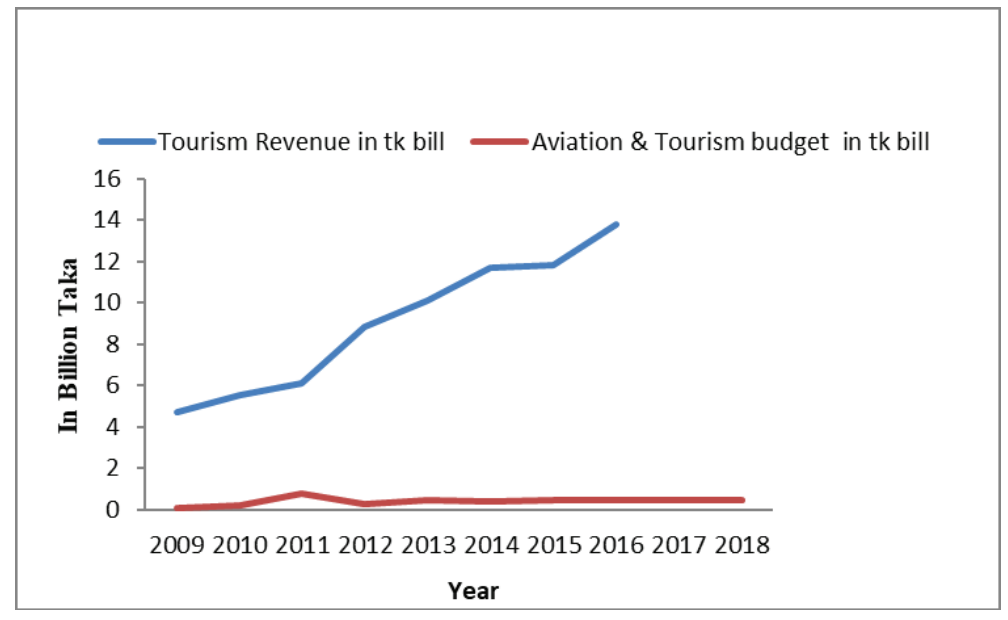

Figure 2. Tourism Budget and Revenue in Bangladesh 2009-2018

\section{Conclusion}

This paper explores the potential of the tourism industry, and scrutinizes the effect of the tourism industry on the overall economic advancement of Bangladesh by analyzing secondary data for eight years. Besides, it presents a detailed idea about the well-known as well as potential tourist spots and areas, tourism administration and tourism organizations, facilities (Visa, accommodation, safety in travelling and currency exchange) for the tourists, infrastructural development, and tourism education in Bangladesh. This paper also scrutinizes data regarding real GDP, tourism budget, tourism revenue, employment in the tourism sector through graphical analysis. This paper exposes that Bangladesh earned USD 1,153 million from its tourism industry during the $2009-2017$ period, which is a small share of its GDP. This study summarizes that the small share of tourism revenue has a limited positive effect on the economic growth of Bangladesh at this moment. Though the tourism sector of Bangladesh suffers from a number of problems, it creates employment, innovation and new technology, technology transfer, new infrastructure, friendship among people, and above all, it helps the brand image of the country, which is "Beautiful Bangladesh." Besides, tourism and hospitality management education is also very popular in Bangladesh. It can be said that the potentiality of the tourism sector is 
not currently fully explored. If it flourishes smoothly, then it will reduce the revenue dependency on other sectors. This paper suggests the following steps to strengthen the torism sector of Bangladesh.

Ground

\begin{tabular}{|c|c|}
\hline Ground & Details Recommendation \\
\hline Need a Long Run Vision & $\begin{array}{l}\text { Bangladesh should make tourism vision for five to ten years to boost up } \\
\text { tourism revenue \& contribution to GDP. It may include } 8 \%-10 \% \text { revenue of } \\
\text { GDP (current figure } 4.4 \% \text { for travel and tourism), infrastructural development } \\
\text { and beautification of the tourist spots, construction and renovation of tourist } \\
\text { sites, highways, naval bases, and aviation facilities. }\end{array}$ \\
\hline $\begin{array}{l}\text { Exploring the tourist } \\
\text { spots }\end{array}$ & $\begin{array}{c}\text { Bangladesh has a large number of magnificent tourist spots and locations, } \\
\text { but these are not well known to the local and foreign tourists. The BPC may } \\
\text { publish books, booklets, handouts, stickers, images, videos (and make it } \\
\text { available to the tourists) to make this site familiar to them (both internal and } \\
\text { foreign tourists). }\end{array}$ \\
\hline $\begin{array}{c}\text { Upgrading the } \\
\text { government tourism } \\
\text { website }\end{array}$ & $\begin{array}{c}\text { The BPC website is dedicated to tourism development, but it is not well } \\
\text { updated. Highly qualified practitioners from the tourism field should be } \\
\text { recruited into this Corporation. A complete list of all tourist sites is not } \\
\text { available on this website. }\end{array}$ \\
\hline $\begin{array}{l}\text { Promotion of tourism } \\
\text { and hospitality } \\
\text { management education }\end{array}$ & $\begin{array}{l}\text { A good number of facilities should be arranged for tourists. For foreign } \\
\text { tourists: one-stop service visa facilities, tourist guide, safety and security in the } \\
\text { spots, special rate in currency exchanges facilities, currency exchange facilities } \\
\text { in the tourist spots, tourist cards for discount and facilities, etc. }\end{array}$ \\
\hline $\begin{array}{l}\text { Employment } \\
\text { opportunity in the } \\
\text { Tourism sector }\end{array}$ & $\begin{array}{c}\text { Education of tourism and hospitality management is one of the most popular } \\
\text { disciplines in Bangladesh. The BPC may encourage young job seekers to join } \\
\text { in the tourism-related agencies by offering special facilities for the tourism } \\
\text { arrangement agencies. }\end{array}$ \\
\hline $\begin{array}{l}\text { BPC Sponsorship for } \\
\text { Domestic Tourism }\end{array}$ & $\begin{array}{l}\text { High schools and colleges need to be coordinated with the BPC and private } \\
\text { tour associations to arrange for study tours for the students. It will train the } \\
\text { young generation with regards to tourism, which will boost up domestic } \\
\text { tourism in the medium as well as the long term. }\end{array}$ \\
\hline $\begin{array}{l}\text { Infrastructural } \\
\text { Development for the } \\
\text { Tourism Sector }\end{array}$ & $\begin{array}{l}\text { Tourism sector of Bangladesh still suffers from the inadequate number of high- } \\
\text { quality roads, especially for waterfalls, beaches, historical monuments in rural } \\
\text { areas, etc. The authority should construct suitable roads and communication } \\
\text { system for both local and foreign tourists. }\end{array}$ \\
\hline $\begin{array}{l}\text { Building up a Strong } \\
\text { Handicrafts Market }\end{array}$ & $\begin{array}{c}\text { Bangladesh has a glorious tradition of exquisite handicrafts. People from } \\
\text { several religions, caste, tribe and villages love to produce handicrafts. There is } \\
\text { a vast possibility to build up a strong handicrafts market in the tourist spots of } \\
\text { Bangladesh. }\end{array}$ \\
\hline $\begin{array}{l}\text { Promote Festival- } \\
\text { centered Tourism }\end{array}$ & $\begin{array}{l}\text { Bangladesh has a rich heritage of diverse cultures, ethnicities, and a large range } \\
\text { of festivals throughout the entire country during different points of time in } \\
\text { the year. If promoted and given support, festival-centered tourism has a bright } \\
\text { prospect in this country. One most colorful of festivals is the Noboborsho } \\
\text { (Bangla New Year Festival), which is on April } 14 \text { each year, and every } \\
\text { community across the country has its own ways of celebrating this Noboborsho } \\
\text { festival. }\end{array}$ \\
\hline
\end{tabular}

"Beautiful Bangladesh" is the official phrase of Bangladesh's tourism industry sector. A large amount of investment from both the government as well as the business community, along with a properly formulated policy framework, is needed to explore the full potential of the tourism industry in Bangladesh. 


\section{References}

Ahmad, S. (2013, March 19). Tourism Industry in Bangladesh, The Daily Star, retrieved from: https://www.thedailystar.net/news/tourism-industry-in-bangladesh

Airways office (2019). Top 10 Travel Agency in Bangladesh, retrieved from: https://airwaysoffice. com/top-10-travel-agency-in-bangladesh/

Akan, Y., İbrahim, A., \& Cem, I., (2007). The 1mpact of tourism on economic growth: The case of Turkey. Journal of Tourism, 9, 1-24.

Ali, M. B. (2013). Socio-economic 1mpacts of tourism development: An empirical study on Cox's Bazar. Asian Journal of Business and Management, 1(4), 205-211.

Ali, A., Amin, S. B., \& Momo, F. T. (2012). The Ethics of Tourism Development in Bangladesh, Paper presented at the $18^{\text {th }}$ Bangladesh Economic Association Biennial Conference, 13 $14^{\text {th }}$ September 2012, Dhaka, Bangladesh. retrieved from: bea-bd.org/site/images/pdf/ new17/12.pdf

Amin, S. B., Murshed, M., \& Rahman, S. (2017, February 8). Role of Rural Tourism Development in Bangladesh Economy, The Daily Sun, retrieved from: https://www.daily-sun.com/printversion/ details/204066/Role-of-Rural-Tourism-Development-in-Bangladesh-Economy

Bangladesh Bureau of Statistics (BBS). (2019). Bangladesh Statistical Yearbook 2018, $38^{\text {th }}$ Edition, P.35, Dhaka: Government of the People's Republic of Bangladesh.

Bangladesh Economic Review (BER). (2019). Macroeconomic situation, P.1-30, Dhaka: Government of the People's Republic of Bangladesh. Retrieved from: https://mof.portal.gov.bd/ site/page/28ba57f5-59ff-4426-970a-bf014242179e/Bangladesh-Economic-Review

Bangladesh Porjoton Corporation (BPC). (2019). Lokkho o Uddessyho (in Bangla), retrieved from:http://www.parjatan.gov.bd/site/page/68c2d54a-112f-4804-8624-9180bf59df98/-

Bhuiyan, A. H., \& Darda, A. (2018). Prospects and potentials of halal tourism development in Bangladesh. Journal of Tourismology, 4(2), 93-106. doi: 10.26650/jot.2018.4.2.0007

Camilleri, M. A. (2018). The Tourism Industry: An Overview, in Travel Marketing, Tourism Economics and the Airline Product, Cham, Switzerland: Springer Nature.

Centre for Economics and Business Research (CEBR). (2018). World Economic League Table 2019, A World Economic League Table with Forecasts for 193 Countries to 2033, Centre for Economics and Business Research. December 2018, 10th Edition , retrieved from: http:// assetsds.cdnedge.bluemix.net/sites/default/files/welt-2019-full-report.pdf

Cetin, G. (2014). Sustaining tourism development through city tax: The case of Istanbul. E-review of Tourism Research, 11.

Choice for Economic and Investment Research (CEIC). (2019). Bangladesh Tourism Revenue. Retrieved from: https://www.ceicdata.com/en/indicator/bangladesh/tourism-revenue

Das, R. K., \& Chakraborty, J. (2012). An evaluative study on tourism in Bangladesh. Research Journal of Finance and Accounting, 3(1), 84-95.

De Esteban, J., Cetin, G., \& Antonovica, A. (2015). Theory of knowledge of tourism: A sociological 
and epistemological reflection. Journal of Tourismology, 1(1), 2-15.

Gökovali, U., \& Bahar, O. (2006). Contribution of tourism to economic growth: A panel data approach. Anatolia, 17(2), 155-167. doi: 10.1080/13032917.2006.9687184

Gokovali, U. (2010) Contribution of tourism to economic growth in Turkey. Anatolia, 21(1), 139 153. doi: $10.1080 / 13032917.2010 .9687095$

Golden Bengal Tours. (2019). Tourism Infrastructure \& Facilities in Bangladesh, retrieved from: https://www.goldenbengaltours.com/tourism-infrastructure.php

Kadir, N., \& AbdKarim, M. Z. (2012). Tourism and economic growth in malaysia: Evidence from tourist arrivals from asean-s countries. Economic Research EkonomskaIstraživanja, 25(4), 1089-1100. doi: 10.1080/1331677X.2012.11517550

knoema.com (2019), Bangladesh-Contribution of Travel and Tourism to GDP as a Share of GDP, retrieved from: https://knoema.com/atlas/Bangladesh/topics/Tourism/Travel-and-TourismTotal-Contribution-to-GDP/Contribution-of-travel-and-tourism-to-GDP-percent-of-GDP

Kobra, M. K., Bhuiyan, K. H., \& Zayed, N. M. (2018). Well and woes of tourism promotion in Bangladesh: Investment perspective. Academy of Accounting and Financial Studies Journal, 22(3), 1-8.

Mahboob, A. M., \& Parvin, R. (2010). Strategic management of tourism sector in Bangladesh to raise gross domestic product: An analysis. AIUB Bus Econ Working Paper Series, No 201004, from: https://orp.aiub.edu/FileZone/abewp/orpadmin-2010-048589862668081/AIUB-BUSECON-2010-04.pdf

Ministry of Environment and Forests (MOEF). (2010). Climate Change and Tourism Industry in Bangladesh, Information Brief, project paper of the Ministry of Environment and Forests, Government of the People's Republic of Bangladesh, Dhaka: Bangladesh. Retrieved from: https://www.iucn.org/sites/dev/files/import/downloads/tourism.pdf

Ohlan, R. (2017). The relationship between tourism, financial development and economic growth in India. Future Business Journal, 3(1), 9-22.

Planning Commission. (2015). Seventh Five Year Plan FY 2016- FY 2020, Accelerating Growth, Empowering Citizens, Final Draft, 11 November 2015, Dhaka : Bangladesh.

Puah, C. H., Jong, M. C., Ayob, N., \& Ismail, S. (2018). The 1mpact of tourism on the local economy in Malaysia. International Journal of Business and Management, 13(12), 151-157.

Rahman, S., \& Chakma, J. (2018, December 14). Tourism Booming with Economy, The Daily Star, retrieved from: https:/www.thedailystar.net/business/news/tourism-boomingeconomy-1673479

Rhaman, M. R. (2016). The Socio-economic Importance of Tourism and Its Impact on the Livelihood in South Asia Case Rangamati, Bangladesh, Bachelor's Thesis, CentriaUniversity of Applied Sciences Degree Programme in Tourism, May 2016, retrieved from: https://www. theseus.fi/bitstream/handle/10024/116404/Rezaur_Rhaman.pdf?sequence=1\&isAllowed=y

Roy, S. C., \& Roy, M. (2015). Tourism in Bangladesh: present status and future prospects. International Journal of Management Science and Business Administration, 1(8), 53-61. doi: 10.18775/ijmsba.1849-5664-5419.2014.18.1006

Salam, R. (2014). Tourism \& socio-economic development: Focus on Bangladesh, a destination country. International Journal of Business \& Management (Toronto), 1(2), 88-98.

Sayeda, T. (2017). The effects of mass tourism: An evaluative study on Cox's Bazar, Bangladesh. 
IOSR Journal Of Humanities And Social Science (IOSR-JHSS), 22(5), 31-36.

Stauvermann, P. J., Kumar, R. R. ., Shahzad, S. J. H., \& Kumar, N. N. (2016). Effect of tourism on economic growth of Sri Lanka: accounting for capital per worker, exchange rate and structural breaks, Economic Change and Restructuring Springer, 51(1), 49-68.

Sultana, S. (2016), Economic contribution of tourism 1ndustry in Bangladesh. Journal of Tourism, Hospitality and Sports, 22, 45-54.

Tourism (2019). InCambridge Academic Content Dictionary online, Cambridge University Press: Cambridge, UK. Retrieved from: https://ictionary.cambridge.org/dictionary/english/tourism

Tourism (2019a). In Collins Dictionary Online, retrieved from: https://www.collinsdictionary.com/ dictionary/english/tourism

Tourism (2019b). In Merriam-Webster Online, retrieved from: https://www.merriam-webster.com/ dictionary/tourism

Trading Economics (2019). Bangladesh GDP, retrieved from: https://tradingeconomics.com/ bangladesh/gdp

The World Travel \& Tourism Council (WTTC) (2009-2018), World Travel \& Tourism Council report 2009-2018, retrieved from: https:/www.wttc.org/economic-impact/country-analysis/ country-data/

UNWTO- United Nation World Tourism Organization (2010), UNWTO Statistics Guidelines 2010, retrieved from: http://www.tugberkugurlu.com/archive/definintion-of-tourism-unwtodefinition-of-tourism-what-is-tourism

Yahya, F., Parameswaran, A., Ahmed, I., \& Sebastian, R. (2005). The economic cost of tourism in Maldives. Annals of Tourism Research, Tourism (Zagreb), 53(1), 33-44. 
